\title{
SOEP
}

SOEPpapers

SOEPna O Y
on Multidisciplinary Panel Data Research
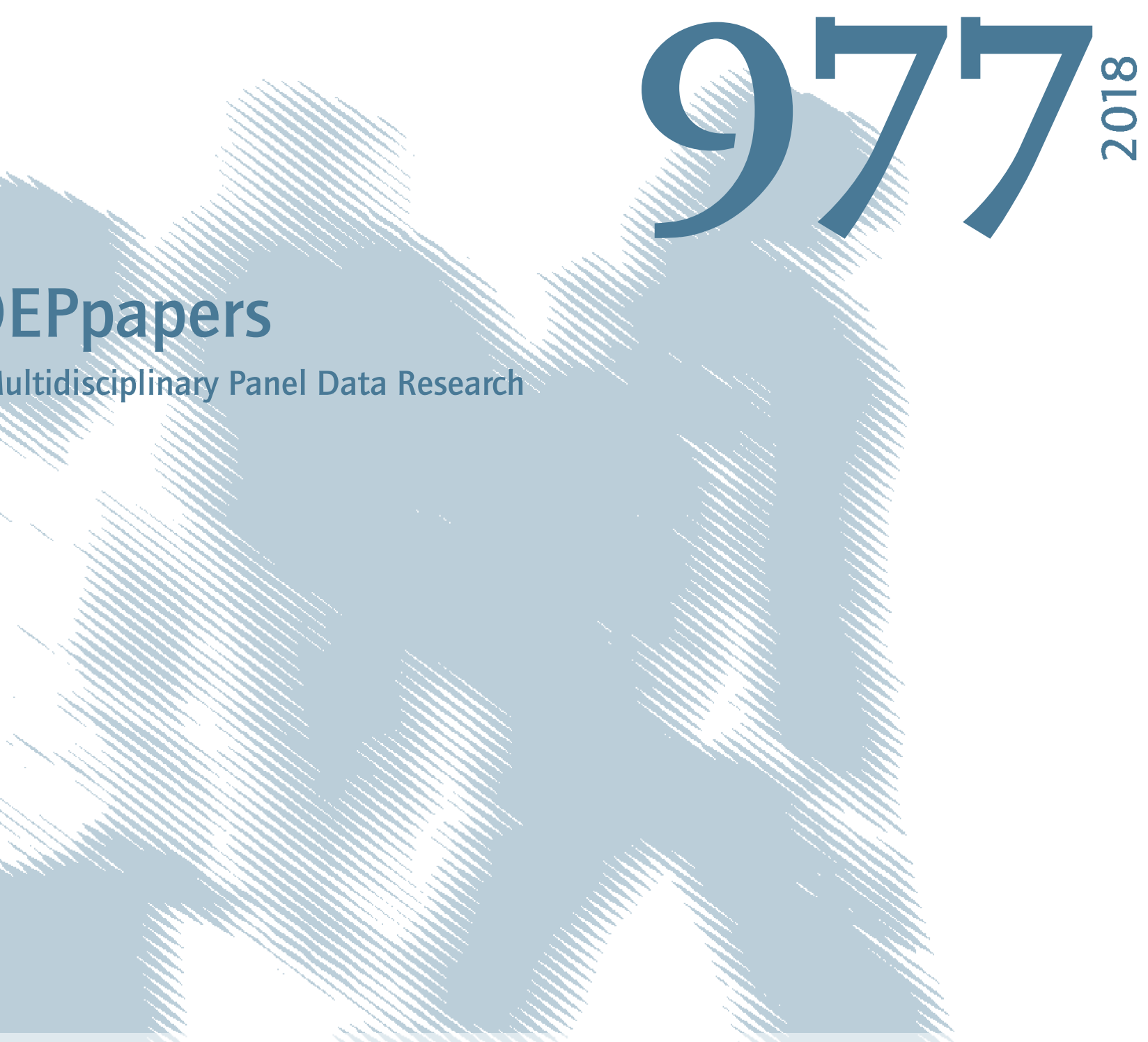

\section{Drivers of Renewable Technology Adoption in the Household Sector}


This series presents research findings based either directly on data from the German SocioEconomic Panel study (SOEP) or using SOEP data as part of an internationally comparable data set (e.g. CNEF, ECHP, LIS, LWS, CHER/PACO). SOEP is a truly multidisciplinary household panel study covering a wide range of social and behavioral sciences: economics, sociology, psychology, survey methodology, econometrics and applied statistics, educational science, political science, public health, behavioral genetics, demography, geography, and sport science.

The decision to publish a submission in SOEPpapers is made by a board of editors chosen by the DIW Berlin to represent the wide range of disciplines covered by SOEP. There is no external referee process and papers are either accepted or rejected without revision. Papers appear in this series as works in progress and may also appear elsewhere. They often represent preliminary studies and are circulated to encourage discussion. Citation of such a paper should account for its provisional character. A revised version may be requested from the author directly.

Any opinions expressed in this series are those of the author(s) and not those of DIW Berlin. Research disseminated by DIW Berlin may include views on public policy issues, but the institute itself takes no institutional policy positions.

The SOEPpapers are available at http://www.diw.de/soeppapers

\section{Editors:}

Jan Goebel (Spatial Economics)

Stefan Liebig (Sociology)

David Richter (Psychology)

Carsten Schröder (Public Economics)

Jürgen Schupp (Sociology)

Conchita D'Ambrosio (Public Economics, DIW Research Fellow)

Denis Gerstorf (Psychology, DIW Research Fellow)

Elke Holst (Gender Studies, DIW Research Director)

Martin Kroh (Political Science, Survey Methodology)

Jörg-Peter Schräpler (Survey Methodology, DIW Research Fellow)

Thomas Siedler (Empirical Economics, DIW Research Fellow)

C. Katharina Spieß (Education and Family Economics)

Gert G. Wagner (Social Sciences)

ISSN: 1864-6689 (online)

German Socio-Economic Panel (SOEP)

DIW Berlin

Mohrenstrasse 58

10117 Berlin, Germany

Contact: soeppapers@diw.de

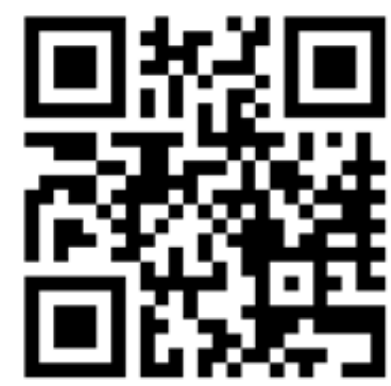




\title{
Drivers of Renewable Technology Adoption in the Household Sector
}

\author{
Anke Jacksohn ${ }^{a, *}$, Peter Grösche ${ }^{b}$, Katrin Rehdanz $z^{a}$ and Carsten Schröder ${ }^{c, d}$ \\ a Kiel University, Department of Economics, Germany \\ ${ }^{\mathrm{b}}$ Anhalt University of Applied Sciences, Bernburg, Germany \\ ' SOEP at DIW Berlin, Germany \\ ${ }^{d}$ Freie Universität Berlin, Berlin, Germany \\ * Corresponding author at Kiel University, Department of Economics, Olshausenstraße 40, 24098 Kiel, \\ Germany. E-mail address: jacksohn@economics.uni-kiel.de
}

\begin{abstract}
Using representative household survey panel data from Germany, we undertake a simultaneous assessment of the importance of factors that have individually been found significant for the adoption of renewable energy systems but have never been tested jointly. These are sociodemographic and housing characteristics, environmental concern, personality traits, and economic factors, i.e. the expected costs of and revenue from the investment. Our results suggest that household decisions to invest in photovoltaic systems and solar thermal facilities are mainly driven by the economic factors. Taking account of sociodemographic and housing characteristics, environmental concern or personality traits has comparatively little relevance, while the quantitative nexus between the decision to invest and returns on the investment is robust to their inclusion.
\end{abstract}

Keywords: renewable technology adoption; investment decision; solar energy; household sector

JEL Codes: C25, D12, Q55 


\section{Introduction}

It is an open question what the main drivers of household decisions to adopt renewable energy technologies are. Are their investment decisions for solar energy systems driven mainly by household characteristics, personality and attitudes, or expected returns on the investment, including public subsidies? A satisfactory answer to this question is of major interest for policymakers attempting to boost the expansion of renewable technologies in the household sector. Finding a satisfactory answer is an empirical task, which has led to a rich literature (see Heiskanen and M atschoss (2017) for a recent overview). This literature focuses on the role of sociodemographic and housing characteristics (e.g., Mills and Schleich, 2009), environmental concern (e.g., Welsch and Kühling, 2009), or personality traits (e.g., Busic-Sontic and Fuerst, 2017). Surprisingly few studies consider the role of expected returns on the investment, i.e. the difference between the expected costs of the investment and the revenue it generates, including public subsidies designed to stimulate such investments (Agarwal et al., 2015; Braito et al., 2017).

To the best of our knowledge, there has been no attempt to integrate all the potential drivers referred to above into one econometric setting systematically exploring the relevance of each of the factors conditioning on the remaining ones. By revealing concealed complementary or substitutive relationships between drivers, however, an approach of this kind would lead to a better understanding of the determinants of household investment decisions. Understanding these conditional relationships is again particularly important for policymakers seeking to encourage renewable technology investments in the household sector in order to foster the contribution of the residential sector to climate protection. The contribution of this paper is to provide such an integrated framework.

Using a large and representative panel survey of households in Germany, we simultaneously assess the importance of all the aforementioned factors for the adoption of renewable energy systems. Specifically, we consider actual household decisions to invest in both photovoltaic (PV) systems for power generation and solar thermal (ST) systems for the provision of warm water and space heating. Extending the survey to include the economic factors "system costs" and "revenue" enables us to distinguish the statistically relevant factors from the irrelevant ones.

The remainder of this paper is structured as follows: Section 2 provides a brief overview of the literature. Section 3 is a description of our data. Section 4 presents our empirical strategy and the results, while Section 5 discusses the latter and concludes. 


\section{Literature review}

The determinants of household investment in building-scale renewable energy systems have drawn considerable interest from researchers during the last two decades. However, the existing studies vary widely in terms of the technologies considered, the research designs applied and determinants taken into account. Balcombe et al. (2013), Heiskanen and M atschoss (2017), and Kastner and Stern (2015) provide general reviews of the literature. Given these comprehensive reviews, here we focus on two aspects particularly relevant for our study. First, we review previous attempts to integrate economic factors into empirical estimations of household investment decisions for renewables. Second, we review studies considering household investment in solar energy systems in Germany.

While several studies consider decision-makers' self-reported financial motives for solar energy system adoption (most recently, see e.g. Michelsen and Madlener, 2016; Palm, 2018), few include investment costs or revenues as such in their empirical adoption models (exceptions are Agrawal et al., 2015; Braito et al., 2017; Rai and Robinson, 2015; Robinson and Rai, 2015; Wasi and Carson, 2013). However, these studies provide evidence that costs and monetary benefits are the decisive drivers of adoption.

Agarwal et al. (2015) base their analysis on a large dataset containing information on the sociodemographic characteristics, location and energy use of households in Southern California. Adding information on PV system costs and local solar irradiation, they calculate the net present value of PV adoption and then employ variance tests to assess the strength of the correlation of PV adoption with sociodemographic characteristics and attainable monetary benefits. They find adoption to be most strongly correlated with monetary benefits, followed by income, education and type of employment of the household members.

Rai and Robinson (2015) develop an empirical agent-based model of residential PV adoption using a comprehensive dataset on households occupying single-family houses in the city of Austin, Texas, between 2004 and 2013. Agents' behaviour in the model is driven by demographic, attitudinal, social network, environmental, and economic variables. The latter incorporate the payback period for the PV investment, which is depends on system costs, utility rebates, tax credits, electricity prices and annual electricity generation by the system. Rai and Robinson (2015) focus on the development, validation and illustrative application of the model. In a related study (Robinson and Rai 2015), the authors investigate which features of the model are most important for accurately describing the adoption process. They show that while the model's economic module performs well in predicting the temporal path of PV diffusion, the inclusion of attitudinal and social factors improves the predictions with regard to spatial and demographic adoption patterns. 
Comparing the effect of different national financial support schemes on household PV investments, Braito et al. (2017) survey adopters and non-adopters of PV systems in one Italian and one Austrian region. Comparing the sociodemographic characteristics and the declared motivations of PV adopters, they find the higher financial support provided in the Italian region to crowd-in younger and less welleducated adopters as well as adopters with economic motives and anthropocentric attitudes to nature.

Wasi and Carson (2017) investigate household decisions to switch to more environment-friendly water heaters before and after the introduction of a rebate programme for hot-water systems in New South Wales. They find that the probability of households choosing a renewable system, i.e. an ST system or a heat pump, increased significantly after the introduction of the programme. Moreover, the impact of the rebate policy differs with household income, education, access to the gas grid, hot water usage, expectations regarding future electricity prices and depending on whether or not households have had to replace the water heater due to a sudden breakdown affecting the system in place before.

The existing studies on household investment in solar energy systems in Germany have examined a broad range of potential determinants but have not incorporated the expected returns on the investment. In the following, we briefly review this literature, focusing on studies using householdlevel data to identify factors influencing the adoption of solar energy systems. ${ }^{1}$ All these studies include a varying set of sociodemographic and housing characteristics (including among others household income, age of the household head, or dwelling type; e.g., Mills and Schleich, 2009; Michelsen and Madlener, 2012). Some also take account of environmental concern (e.g. Welsch and Kühling, 2009) or personality traits (Busic-Sontic and Brick, 2018; Busic-Sontic and Fuerst, 2017).

M ills and Schleich (2009) were among the first to investigate the adoption of ST systems by households in Germany. Using survey data and drawing upon a large set of explanatory variables (sociodemographic and dwelling characteristics, appliances, energy consumption, solar radiation), they obtain mixed results and establish the statistical insignificance of most sociodemographic variables.

Michelsen and Madlener (2012, 2013 and 2016) consider decision-makers' motives for adopting a heating system run on renewable energy. They investigate the motivation (M ichelsen and Madlener, 2013) for the (non-)adoption of a specific system and the parameters affecting the decision (M ichelsen

\footnotetext{
${ }^{1}$ By focussing on studies assessing actual adoption behaviour, we omit those based on stated preferences. M ost recent examples include Alyousef et al. (2016) for PV systems and Kastner and M atthies (2016) for ST systems. We also exclude studies using qualitative and descriptive methods concentrating predominantly on the decisionmakers' motivations (Karakaya et al. 2015; Kotilainen et al. 2017; Sonnberger 2015) or lifestyle (Gröger et al. 2011).
} 
and M adlener, 2012 and 2016). The authors concede that the information value of the results is limited by the circumstance that their dataset consists of households that had invested in a renewable heating system and had actively applied for a government grant (M ichelsen and M adlener, 2013: 225).

Welsch and Kühling (2009) use household survey data from the Hanover region to investigate the effect of sociodemographic characteristics and attitudes to the environment on (inter alia) the adoption of ST systems. The results are ambiguous with respect to environmental concern. People who fear nuclear power are more likely to possess an ST system, but people who state that a switch to renewable energy is necessary are actually less likely to have a solar system.

More recently, Busic-Sontic and Brick (2018) and Busic-Sontic and Fuerst (2017) have examined the influence of personality traits on home-owners' decisions to invest in solar or other renewable energy systems. Both analyses draw upon the German Socio-Economic Panel (SOEP), a representative longitudinal survey of private households in Germany. They control for environmental concern, risk preferences, sociodemographic characteristics, solar irradiance at state level and dwelling type. Unlike earlier studies that only consider ST systems, their studies also include investments in PV and other renewable energy systems without, however, differentiating between these technologies in the analysis.

Estimating duration models, Busic-Sontic and Fuerst (2017) find no effect of personality traits on the adoption decision, while all the control variables except for risk preferences yield statistically significant effects. The investment probability increases with environmental concern, income, the number of children and solar irradiance. It is higher among male and well-educated decision-makers, whereas it decreases with age, the number of dwellings in the respective building and year. Employing a multiple mediator bootstrapping model, Busic-Sontic and Brick (2018) show that personality traits affect the investment probability not directly but indirectly through environmental concern yet not through risk preferences.

We build on the existing literature by taking into account the factors examined therein, namely environmental concern and personality traits as well as sociodemographic and housing characteristics, and add to it by integrating all these factors, costs and attainable revenue into one econometric framework. 


\section{Data}

Our empirical analysis draws upon the German Socio-Economic Panel (SOEP), a representative annual household survey for Germany. We use the period 2007-2015. ${ }^{2}$ This panel provides us with information on household investment decisions for PV and ST systems as well as sociodemographic and housing characteristics, environmental concern and personality traits. We enrich the data with auxiliary information on technology-specific costs and attainable revenues. Overall, we have five sets of variables:

- a (multinominal) choice variable, referring to whether a household has adopted a solar energy system (either PV or ST or a combination of both) or whether the household had not invested;

- two economic factors connected with the solar energy system, i.e. the (potential) installation costs and the expected revenue;

- variables pertaining to environmental concern and personality traits;

- sociodemographic variables and variables related to housing conditions;

- some further control variables.

The following subsections go into more detail on these sets of variables.

\subsection{Technology choice}

Starting in 2007, SOEP households are asked whether their dwelling is equipped with a solar energy system. In 2015, this question was supplemented with an inquiry into the specific system type: a PV system and/or an ST system. Due to the panel structure of the data, i.e. the repeated observation of the same households, we can deduce the information on the type of solar energy system - PV, ST, or a combination of both technologies - prior to 2015 for households that did not move. Our (dependent) technology choice variable is thus a discrete variable with four categories. Again by using the panel structure, we can identify the year in which the household installed the solar energy system (if any) by comparing the household information from the subsequent with the preceding year.

\subsection{Economic factors}

The technology-specific cost of installing a solar energy system and the respective attainable revenue may influence a household's investment decision, so we include them as economic factors in our analysis. We obtain annual data on PV and ST system costs from Altenhöfer-Pflaum and Horbelt (2017)

\footnotetext{
2 The SOEP is an ongoing longitudinal survey of approximately 21,000 adult respondents, conducted annually since 1984 (see Wagner et al., 2007). We use SOEP v32.
} 
and the Baukosteninformationszentrum Deutscher Architektenkammern (BKI, 2008-2015) and convert these figures to cost per square meter of surface installed (see Appendix A for details). Figure 1 shows the progression of PV and ST system costs in the years 2008 to 2015. Over that period, the costs for PV systems decreased appreciably, whereas there was a slight overall increase in the costs for ST systems. ${ }^{3}$

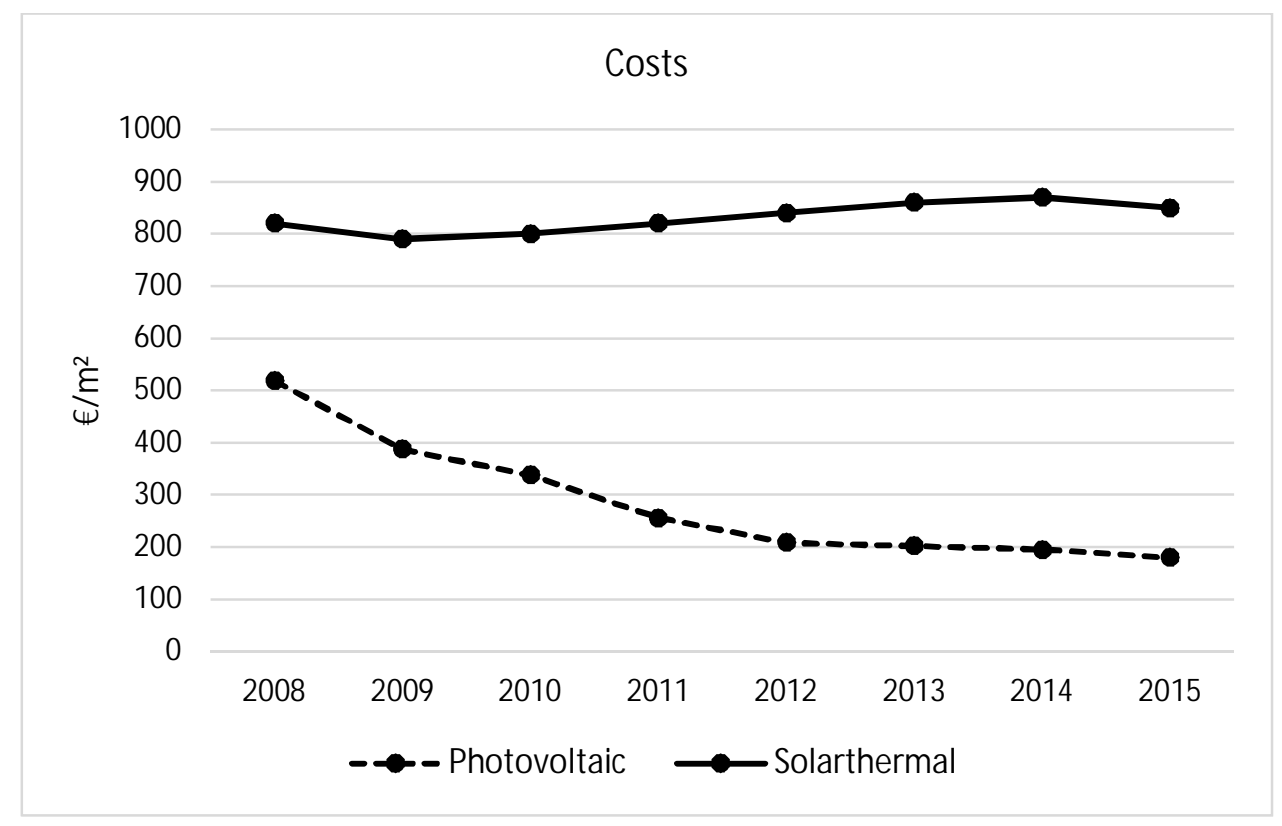

Source: Own presentation based on data from Altenhöfer-Pflaum and Horbelt (2017) and BKI (2008-2015)

Figure 1. Trends in photovoltaic and solar thermal system costs

Unlike costs, revenues attainable with a solar energy system do not only vary with the technology but also depend on the solar irradiance at the respective household's location and the subsidy scheme in in operation. No single data source provides comprehensive information on these factors, so we combine data from several sources to generate the revenue variable (see Appendix A for details). We measure annual revenue and one-time investment costs in euros per square meter of surface installed. Figure 2 shows how revenues for PV and ST systems developed between 2008 and 2015. The black lines stand for the revenue attainable with mean annual global radiation in Germany, while the grey lines show the revenue attainable with maximum and minimum annual global radiation in Germany. ${ }^{4}$

\footnotetext{
${ }^{3}$ Note that in Germany, households investing in an ST system can apply for a subsidy administered by the German government. The subsidy scheme is highly differentiated in terms of system type and size and the systems have to fulfil certain technical requirements in order to qualify (see e.g. Bundesministerium für Wirtschaft und Energie, 2015). Since we rely on average system prices, it is not possible to account for subsidization. Our cost estimates are presumably somewhat upwardly biased.

${ }^{4}$ According to Germany's National M eteorological Service, the Deutscher Wetterdienst (DWD), mean annual global radiation in Germany amounts to $1054 \mathrm{kWh}$ /year, while maximum and minimum global radiation amounts to $1261 \mathrm{kWh} /$ year and $951 \mathrm{kWh} /$ year, respectively. See the DWD homepage for further details.
} 
The decline in revenue attainable with a PV system is due to the adaption of the feed-in tariff to declining system costs. The small fluctuations in the revenue attainable with an ST system are due to changes in gas prices (see Appendix A for more details on the calculation).

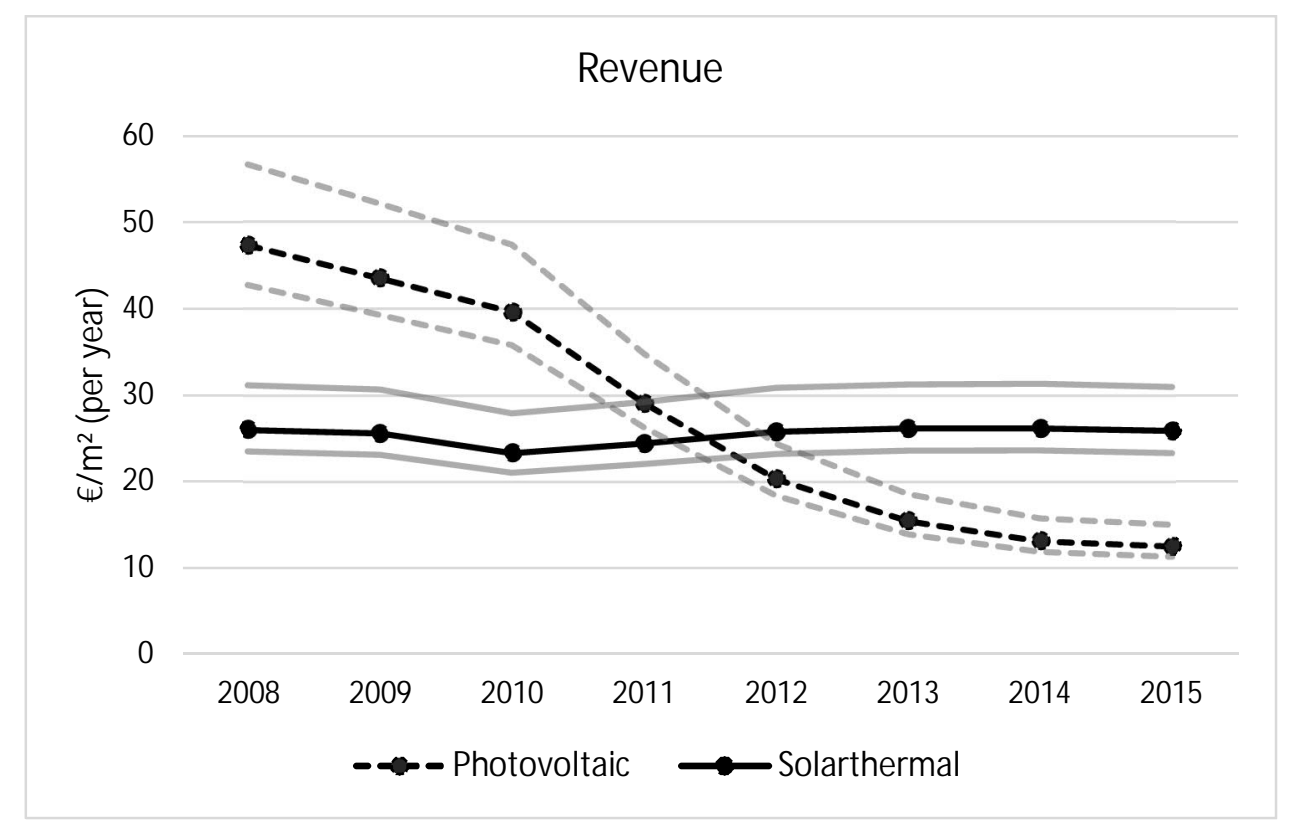

Source: Own presentation. See Table A1 for relevant data sources.

Figure 2. Trends in attainable annual revenue

\subsection{Environmental concern and personality traits}

The use of solar technology is a form of environment-friendly behaviour and thus may be triggered by strong pro-environmental preferences. The SOEP surveys concern for environmental protection. ${ }^{5}$ To derive a stable measure of environmental concern, unaffected by recent news of environmental problems, we average the responses of the household head ${ }^{6}$ over the last two years.

An individual's personality may be another factor determining the decision whether or not to invest in solar technology. A person who is aware of environmental problems may be even more likely to behave in an environment-friendly way if that person has a general sense of responsibility. A fearful person,

\footnotetext{
${ }^{5}$ The three-digit scale ranges from "not concerned at all" and "somewhat concerned" to "very concerned".

${ }^{6}$ In the SOEP, the household head is the person who knows best about matters concerning the household and hence answers the household questionnaire (Haisken-DeNew and Frick, 2005). In some households, different persons identify as head of the household in different years. To ensure consistency, we define the person who most frequently assumes this role during the years considered in our analysis as the sole head of the respective household.
} 
on the other hand, may be reluctant to adopt a solar energy system because of the monetary risk associated with the investment. Likewise, very traditional moral values may cause a strong disposition to maintain the status quo.

We capture personality traits by the "Big 5" (see, e.g. Costa and M cCrae, 1992; M cCrae and Costa, 2008), a personality model well-known in psychology. The five dimensions of personality are openness, conscientiousness, extraversion, agreeableness and neuroticism (see Costa and M cCrae, 1992; M cCrae and Costa, 2008).

Openness measures the extent to which individuals are artistic, imaginative, original, curious and have diverse interests. Individuals scoring highly on conscientiousness exhibit a pronounced impulse control and act in a goal- and task-oriented way. They tend to proceed in an organized and efficient manner and to be reliable, responsible and thorough. Extraversion implies an active and energetic approach towards the world and encompasses facets like sociability, assertiveness and enthusiasm. Individuals with high scores in agreeableness are pro-social and communally-minded and tend to be altruistic, trusting, forgiving and modest. Neuroticism is defined as negative emotionality, i.e. individuals scoring highly in this dimension tend to feel anxious, nervous, sad and tense (John et al., 2008; M cCrae and John, 1992).

Standard inventories for the assessment of the Big Five like the 240-item Revised Personality Inventory (NEO-PI-R, Costa and M cCrae, 1992) or even the shorter 44-item Big Five Inventory (BFI, John et al., 1991) are too time-consuming for respondents to answer as part of a broad, multi-topic survey like SOEP. Therefore, an inventory consisting of 15 to 16 items (BFI-S) was developed and used in SOEP waves 2005, 2009 and 2013 (Gerlitz and Schupp, 2005). ${ }^{7}$ We primarily use the data from 2009 and replenish missing information on household heads' personality traits with data from $2013 .{ }^{8}$

Each trait dimension consists of a number of items. To calculate the respondents' scores in the respective dimensions of personality, we divide the sum of all values of the corresponding items by the number of items in the dimension. Table 1 shows summary statistics for environmental concern and personality traits.

\footnotetext{
${ }^{7}$ The original $\mathrm{BFI}$-S inventory consisted of three items per dimension. A fourth item for measuring openness was added in 2009 and 2013 (Richter et al., 2017).

${ }^{8}$ Personality traits are fairly stable throughout adulthood (see Ferguson, 2010; Lucas and Donnellan, 2011; Specht et al., 2011).
} 
Table 1. Definitions and summary statistics for environmental concern and personality traits $(N=24,136)$

\begin{tabular}{|c|c|c|c|c|c|}
\hline Variable & Definition & Mean & Std. Dev. & Min & Max \\
\hline Concern & $\begin{array}{l}\text { Environmental concern reported by the } \\
\text { household head, average over the } \\
\text { previous two years measured on a } 1 \text { ("not } \\
\text { concerned at all") to } 3 \text { ("very concerned") } \\
\text { scale }\end{array}$ & 2.148 & 0.532 & 1 & 3 \\
\hline Consc $^{a}$ & Conscientiousness & 5.877 & 0.877 & 2.333 & 7 \\
\hline Extrava & Extraversion & 4.719 & 1.112 & 1 & 7 \\
\hline Agree $^{a}$ & Agreeableness & 5.314 & 0.960 & 1 & 7 \\
\hline Open ${ }^{a}$ & Openness & 4.677 & 1.053 & 1 & 7 \\
\hline Neuro ${ }^{a}$ & Neuroticism & 3.670 & 1.204 & 1 & 7 \\
\hline
\end{tabular}

${ }^{a}$ All personality traits are measured with three items on a 1 ("does not describe me at all") to 7 ("describes me perfectly") scale; the exception is openness, which is measured with four items on the 1 to 7 scale.

\subsection{Sociodemographic and housing characteristics}

Regarding the sociodemographic characteristics, we draw information on the households' equivalent annual net income as well as the household composition (number of adults and children) from the SOEP. At the individual level, we control for gender, age and education of the heads of households.

With respect to housing conditions, we take account of the type of dwelling (house/apartment) and whether the household lives in a rural area. Table 2 displays definitions and summary statistics for the sociodemographic and housing characteristics. 
Table 2. Definitions and summary statistics for sociodemographic and housing characteristics $(\mathrm{N}=\mathbf{2 4 , 1 3 6 )}$

\begin{tabular}{|c|c|c|c|c|c|}
\hline Variable & Definition & Mean & Std. Dev. & Min & Max \\
\hline Age & Age of the household head in years & 59.356 & 13.542 & 20 & 101 \\
\hline Female & $\begin{array}{l}1 \text { if the household head is female, } 0 \\
\text { otherwise }\end{array}$ & 0.363 & 0.481 & 0 & 1 \\
\hline LowEdu & $\begin{array}{l}1 \text { if the highest level of education } \\
\text { achieved by household head is } \\
\text { intermediate secondary school, lower } \\
\text { secondary school, other, or none, } 0 \\
\text { otherwise }\end{array}$ & 0.080 & 0.271 & 0 & 1 \\
\hline MediumEdu & $\begin{array}{l}1 \text { if highest level of education achieved by } \\
\text { the household head is university entrance } \\
\text { diploma, advanced technical college } \\
\text { entrance qualification, apprenticeship or } \\
\text { specialized vocational school, } 0 \text { otherwise }\end{array}$ & 0.602 & 0.490 & 0 & 1 \\
\hline HighEdu & $\begin{array}{l}1 \text { if highest level of education achieved by } \\
\text { the household head is school of health } \\
\text { care, specialized college of higher } \\
\text { education, post-secondary technical, } \\
\text { college, technical university, civil service } \\
\text { training, } 0 \text { otherwise }\end{array}$ & 0.319 & 0.466 & 0 & 1 \\
\hline Eqlncome & $\begin{array}{l}\text { Equivalent annual net income (in } € \text { ) after } \\
98 \% \text { winsorization by year }{ }^{\mathrm{a}}\end{array}$ & 26330.150 & 13967.310 & 6670 & 87658.660 \\
\hline Adults & Number of adults living in the household & 2.045 & 0.758 & 1 & 7 \\
\hline Children & $\begin{array}{l}\text { Number of children ( }<18 \text { years) living in } \\
\text { the household }\end{array}$ & 0.358 & 0.768 & 0 & 8 \\
\hline House & $\begin{array}{l}1 \text { if the household lives in a 1-2-family } \\
\text { house, } 0 \text { if the household lives in an } \\
\text { apartment }\end{array}$ & 0.820 & 0.384 & 0 & 1 \\
\hline Rural & $\begin{array}{l}1 \text { if the household is located in a rural } \\
\text { area, } 0 \text { otherwise }\end{array}$ & 0.374 & 0.484 & 0 & 1 \\
\hline
\end{tabular}

\footnotetext{
a Equivalent income is household income divided by the number of household members weighted according to the modified OECD scale, which assigns a weight of one to the first adult household member, a weight of 0.5 to each additional adult and a weight of 0.3 to each child in the household (OECD, 2013).

${ }^{b}$ The SOEP uses a condensed version of the spatial categorisation provided by the Federal Institute for Research on Building, Urban Affairs and Spatial Development (BBSR). The BBSR categorisation is based on the share of the population of a county (Landkreis) living in towns with more than 20,000 inhabitants, the population density without consideration of these towns and the overall population density (M ilbert, 2015).
} 


\subsection{Further control variables}

We use the information on the dwelling's construction year provided in the SOEP to create a dummy variable that indicates whether the household is legally obliged to use renewable energies to cover part(s) of the building's heat demand. ${ }^{9}$ Furthermore, the year of the interview serves as time trend.

Table 3. Definitions and summary statistics for the control variables $(\mathrm{N}=\mathbf{2 4 , 1 3 6 )}$

\begin{tabular}{llcccc}
\hline Variable & Definition & Mean & Std. Dev. & Min & Max \\
\hline Obligation & $\begin{array}{l}\text { 1 if household is obliged by law to use } \\
\text { renewable energies, 0 otherwise }\end{array}$ & 0.003 & 0.054 & 0 & 1 \\
Year & \begin{tabular}{l} 
Survey year \\
\hline
\end{tabular} & 2011.891 & 2.280 & 2008 & 2015 \\
\hline
\end{tabular}

\subsection{Construction of the working sample}

For our analyses, we do not consider all SOEP households but construct a working sample appropriate for our purposes. First, we restrict our attention to households owning their accommodation, because only owners can decide whether or not to invest in a renewable facility at their own discretion. Second, we omit households living in high-rise buildings, since it is highly unlikely that they will be able to install a renewable facility on their own account. Third, we exclude households providing inconclusive information, for instance households that have moved to dwellings already equipped with solar energy systems, i.e. where the investment decision was taken by another household. Fourth, along the same lines we also exclude all observations from 2007, the first year when solar installations were surveyed, because installations existing in 2007 lack information about the specific time of investment (and hence about costs and revenue, see Section 3.2). Finally, since solar energy systems are durable goods with a life span of twenty years or more (Wesselak et al. 2017), we exclude households once they have invested (in the post-investment phase). The operative assumption here is that the system installed will not be renewed within the investigation period. Table B1 details the various restrictions we imposed and the resulting changes in sample size.

Our final sample covers the years from 2008 to 2015 and encompasses 4,265 households in owneroccupied dwellings and 24,136 cases. Of these, 129 households invested in a PV system, 131 households in an ST system and 31 households in a combination of both. Table 4 displays the size of the working sample and the households' decisions per year.

Table 4. Size of the working sample by year and choice

\footnotetext{
${ }^{9}$ Since January 2009, owners of newly constructed buildings are required by law to use renewable energies to cover part(s) of the buildings' heating demand. ST systems fulfil this legal requirement directly, while PV systems are recognised as surrogate measures (Erneuerbare Energien Wärme Gesetz, 2008).
} 


\begin{tabular}{cccccc}
\hline Year & No solar & PV & ST & Both & Total \\
\hline 2008 & 2,416 & 9 & 16 & 5 & 2,446 \\
2009 & 2,434 & 13 & 27 & 10 & 2,484 \\
2010 & 2,463 & 15 & 14 & 7 & 2,499 \\
2011 & 2,487 & 14 & 18 & 3 & 2,522 \\
2012 & 3,117 & 28 & 14 & 2 & 3,161 \\
2013 & 3,608 & 21 & 14 & 1 & 3,644 \\
2014 & 3,631 & 17 & 13 & 2 & 3,663 \\
2015 & 3,689 & 12 & 15 & 1 & 3,717 \\
\hline Total & 23,845 & 129 & 131 & 31 & 24,136 \\
\hline
\end{tabular}

\section{Econometric analysis}

\subsection{Estimation approach}

At any point in time $t$ a household $h$ faces $j=1, \ldots 4$ different choice alternatives: not to invest at all ("No solar"); to invest in a PV but not in an ST system ("PV"); to invest in an ST but not in a PV system ("ST"); or to invest in both a PV and an ST system ("Both"). Households that have invested neither in a PV nor in a ST system until period $t$ face all four alternatives again in $t+1$. However, if a household has decided to invest in either or both of the solar systems until period $t$, we assume it will make no further investments of this kind in future. Accordingly, we remove such households from the data set for all periods after $t$ (see Section 3.6).

We rely on the random utility framework to capture the household's choice among the four alternatives. Let $U_{i j}$ be the utility that case $i$ (household $h$ in time $t$ ) derives from alternative $j$. The household will choose the alternative providing the greatest utility. The utility comprises of an observed (deterministic) part $V_{i j}$ and an unobserved (random) part of utility $\varepsilon_{i j}$ :

$$
U_{i j}=V_{i j}+\varepsilon_{i j}
$$

We assume that the utility of a given choice alternative is affected by the expected costs and revenue of the investment (including public subsidization), environmental concern and personality traits of the head of the household, sociodemographic and housing characteristics, and the further control variables, i.e. the mandatory use of renewable energy and a time trend. We specify the deterministic utility as

$$
V_{i j}=a_{j}+\sum_{l} \gamma_{l} x_{i l}+\sum_{m} \beta_{m} w_{i j m}
$$


where $\mathrm{a}_{\mathrm{j}}$ is the alternative-specific constant and $x_{i l}$ denotes the $l$ case-specific variables (sociodemographic and housing characteristics, environmental concern and personal traits, and the further control variables) that vary over cases $i$ but are constant across the four alternatives. The term $w_{i j m}$ contains the $m$ variables that vary over cases $i$ and alternatives $j$, for instance the investment costs and the expected revenue associated with a PV system for a household in a specific year. To compare the effect sizes of the variables, we standardize every explanatory variable by subtracting the respective mean and dividing by the respective standard deviation.

We assume that the unobserved (random) part of utility $\varepsilon_{i j}$ follows an extreme-value distribution such that the choice probability $P_{i j}$ of case $i$ for alternative $j$ is of logit form (Train, 2009):

$$
P_{i j}=\frac{e^{V_{i j}}}{\sum_{j} e^{V_{i j}}}
$$

Since a specific household $h$ may appear repeatedly in our data set (as long as it has decided not to invest in a solar system), the random part of utility might exhibit a correlation structure between several cases $i$. To take this correlation into account, we apply the clustered version of the HuberWhite sandwich estimator of the variance.

In order to test the explanatory power of the potential drivers of the household's decision to adopt renewable energy technologies - economic factors, environmental concern and personality traits, or sociodemographic and housing characteristics - we estimate three different specifications of equation (2). The first specification (Model 1) is the most comprehensive one, i.e. it includes all three sets of explanatory variables. To explore the explanatory power of the respective groups of variables, we compare Model 1 to more parsimonious specifications. In Model 2, we exclude the set of variables related to environmental concern and personality traits. In M odel 3, we additionally exclude the set of sociodemographic and housing variables. All three models contain the dummy for mandatory use of renewable energy and the time trend.

\subsection{Regression results}

Table 5 shows the results of our three regression models. In all three models, "No solar" constitutes the reference category used to normalize the location of the deterministic utility. The respective coefficients measure the average effect on the deterministic utility, the cluster-robust standard errors are put in parentheses. Furthermore, Table 5 reports the number of cases, the log-pseudolikelihood, Akaike's information criterion (AIC) and Schwarz's Bayesian information criterion (BIC) for the respective models. 
Since the variables are standardized, the magnitude of the effect is comparable between variables. The results of Model 1 reveal that the economic factors, i.e. costs and revenue, have the largest coefficients among the variables and thus exert the biggest effect on the investment decision. In line with our expectations, the probability that alternative $j$ is chosen increases with its revenue and decreases with its costs.

By contrast, the set of preference and trait variables have almost no effect on the choice probabilities. Environmental concern has a weakly significant positive effect on the probability of opting for a PV system, while conscientiousness has a weakly significant negative effect on the same.

Considering the sociodemographic and housing characteristics, we find mixed results. While the household heads' sociodemographic characteristics affect the choice probability for PV systems, i.e. households with younger heads are more prone to purchase a PV system and households with female or better-educated heads are less prone to do so, they have hardly any effect on the choice of ST systems. Equivalent income affects the choice probability of both solar technologies positively, the effect being much larger for PV systems. ${ }^{10}$ Moreover, the probability of investing in an ST system increases with the number of adults in the household, while the probability of investing in a PV system increases with the number of children. Living in a rural area has a positive effect on the choice probability for PV systems, while living in a house as opposed to an apartment has a positive effect on the choice probability for PV as well as for ST systems.

As for the remaining control variables, we find that households living in a new building and being obliged by law to use renewable energies to cover part(s) of the buildings' heat demand are more likely to invest in any of the systems, the effect being most pronounced in the ST case. Lastly, the probability of investing in a combination of both systems is negatively affected by the year of the interview. This matches the distribution of installations over the survey years displayed in Table 1. In this context, note also that the results for the combination of both systems may be generally impaired by the small number of households choosing this alternative.

Turning to the comparison of the models' explanatory power, the value of the likelihood function is largest for the most comprehensive model 1 and this model thus exhibits the best fit to the data. But does switching from Model 1 to the more parsimonious M odels 2 and 3 result in a substantial loss of explanatory power? We guide our decision by the two information criteria AIC and BIC. The smaller values of $\mathrm{AIC}$ and $\mathrm{BIC}$ in Models 2 and 3 reveal that the exclusion of environmental concern and personal traits yields no severe loss in terms of explanatory power. M odel 2 performs best in terms of

\footnotetext{
${ }^{10}$ We tested the inclusion of different functional forms of the income variable (linear, quadratic, and cubic polynomials as well as logarithmic) and found that the logarithmic variant fits best in terms of AIC and BIC. The corresponding regression outputs can be found in Table B2 in the appendix.
} 
the AIC that weighs model fit against a parsimonious specification, while Model 3 performs best in terms of the BIC, which does the same but penalizes model complexity more strictly.

Table 5 also shows that despite the exclusion of (sets of) variables the effect of the remaining variables on the deterministic utility (and hence the choice probabilities) persists, with only slight changes in the size of the coefficients. This parameter stability gives us an indication that our (sets of) explanatory variables are rather uncorrelated. We further conduct Wald tests to test for the equality of the costs (revenue) coefficients across models and cannot reject the null hypothesis of the costs (revenue) coefficients being equal. ${ }^{11}$

\footnotetext{
${ }^{11}$ Pairwise tests for the equality of the costs (revenue) coefficients across models 1-3 yield $p$-values between 0.229 and 0.846 ( 0.323 and 0.440 ). The test for the equality of costs (revenue) coefficients across all three models yields a $p$-value of $0.476(0.539)$. See tables B3 and B4 for details.
} 
Table 5. Regression results

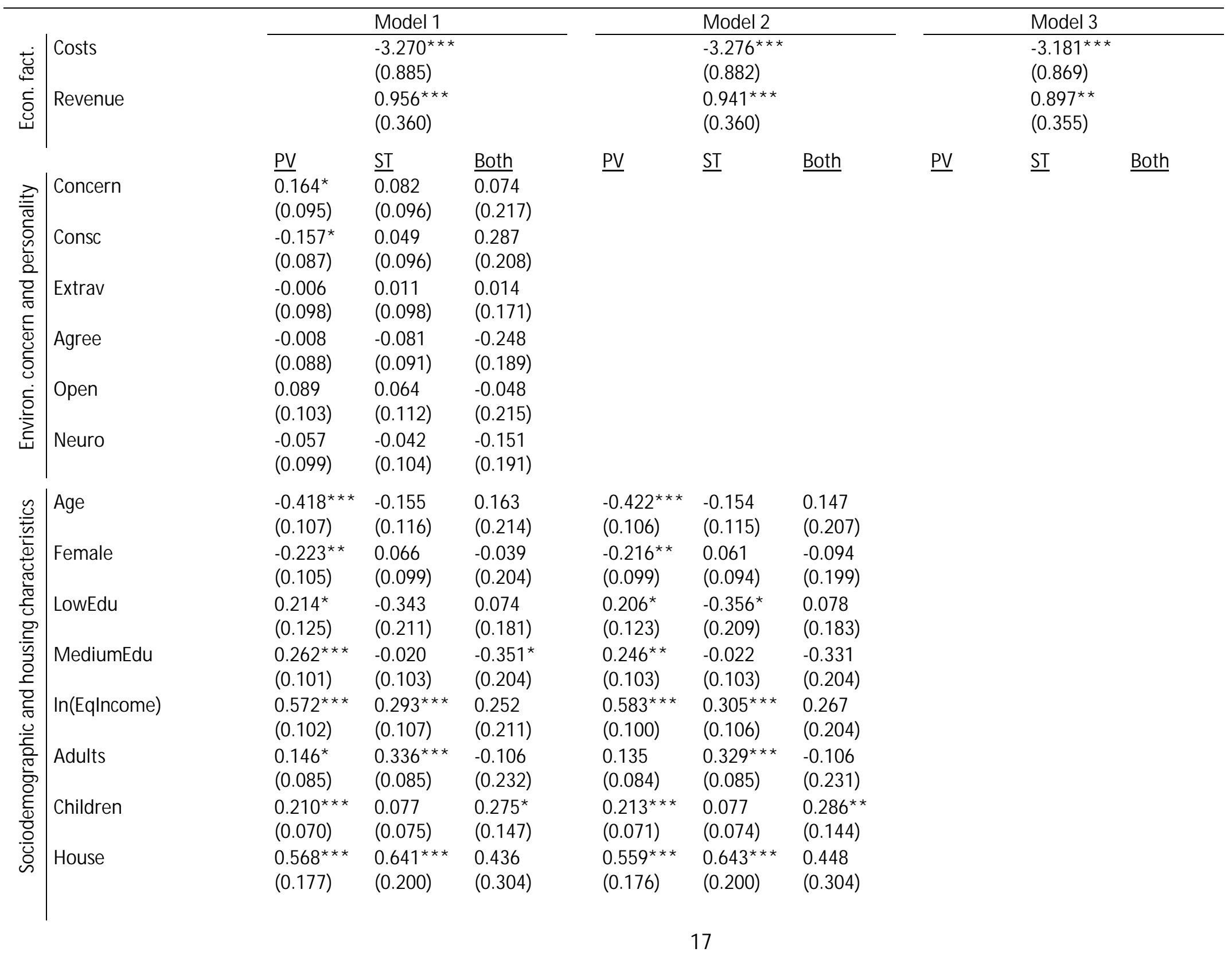




\begin{tabular}{|c|c|c|c|c|c|c|c|c|c|c|}
\hline & Rural & $\begin{array}{l}0.325^{* * *} \\
(0.091)\end{array}$ & $\begin{array}{l}0.163^{*} \\
(0.096)\end{array}$ & $\begin{array}{l}-0.263 \\
(0.235)\end{array}$ & $\begin{array}{l}0.317^{* * *} \\
(0.091)\end{array}$ & $\begin{array}{l}0.160^{*} \\
(0.096)\end{array}$ & $\begin{array}{l}-0.265 \\
(0.237)\end{array}$ & & & \\
\hline & Obligation & $\begin{array}{l}0.132 * * * \\
(0.028)\end{array}$ & $\begin{array}{l}0.245^{* * *} \\
(0.018)\end{array}$ & $\begin{array}{l}0.164 * * * \\
(0.063)\end{array}$ & $\begin{array}{l}0.133^{* * *} \\
(0.028)\end{array}$ & $\begin{array}{l}0.246 * * * \\
(0.018)\end{array}$ & $\begin{array}{l}0.168 * * * \\
(0.060)\end{array}$ & $\begin{array}{l}0.163^{* * *} \\
(0.026)\end{array}$ & $\begin{array}{l}0.263 * * * \\
(0.016)\end{array}$ & $\begin{array}{l}0.177 * * * \\
(0.056)\end{array}$ \\
\hline & Year & $\begin{array}{l}-0.036 \\
(0.301)\end{array}$ & $\begin{array}{l}-0.147 \\
(0.108)\end{array}$ & $\begin{array}{l}-0.891^{* * *} \\
(0.287)\end{array}$ & $\begin{array}{l}-0.061 \\
(0.300)\end{array}$ & $\begin{array}{l}-0.150 \\
(0.108)\end{array}$ & $\begin{array}{l}-0.908^{* * *} \\
(0.287)\end{array}$ & $\begin{array}{l}-0.134 \\
(0.300)\end{array}$ & $\begin{array}{l}-0.194^{*} \\
(0.107)\end{array}$ & $\begin{array}{l}-0.919 * * * \\
(0.285)\end{array}$ \\
\hline & Constant & $\begin{array}{l}-4.887 * * * \\
(0.672)\end{array}$ & $\begin{array}{l}0.914 \\
(2.014)\end{array}$ & $\begin{array}{l}-3.602 * * * \\
(1.266)\end{array}$ & $\begin{array}{l}-4.825 * * * \\
(0.672)\end{array}$ & $\begin{array}{l}0.969 \\
(2.007)\end{array}$ & $\begin{array}{l}-3.508^{* * *} \\
(1.268)\end{array}$ & $\begin{array}{l}-4.327 * * * \\
(0.661)\end{array}$ & $\begin{array}{l}1.182 \\
(1.980)\end{array}$ & $\begin{array}{l}-3.294 * * * \\
(1.248)\end{array}$ \\
\hline & Number of cases & & 24,136 & & & 24,136 & & & 24,136 & \\
\hline & Log pseudolikelihood & & -1638.231 & & & -1644.864 & & & -1739.761 & \\
\hline & AIC & & 3388.462 & & & 3365.729 & & & 3501.523 & \\
\hline & $\mathrm{BIC}$ & & 3919.217 & & & 3725.883 & & & 3605.778 & \\
\hline
\end{tabular}




\section{Discussion and conclusion}

The present paper simultaneously assesses the importance of sociodemographic and housing characteristics, environmental concern, personality traits and expected returns on household investments in PV and ST systems using a large-scale representative household survey for Germany. All in all, our results show that while sociodemographic and housing characteristics, in particular equivalent income and dwelling type, explain part of the investment decision, it is mainly the costs and revenues associated with investments that matter. The coefficients of the standardized costs and revenues are much larger than all the other coefficients. It seems that sociodemographic and housing characteristics only 'fine-tune' the choice probabilities, while environmental concern and personality traits are insignificant. Accordingly, analyses of adoption choices from renewable energy systems that restrict themselves to preferences and personality traits (plus sociodemographic variables) provide only limited insights because they take no account of what is by far the most relevant information. For the validity of previous research that has relied on more parsimonious data sets or models not containing these 'soft factors', our results provide no indications that the estimates suffer substantially from unobserved variable bias.

From a policy perspective, our results suggest that 'soft factors' like reported pro-environmental preferences or certain manifestations of personality traits like e.g. altruistic/agreeable personalities cannot serve as a substitute for actual (publicly provided) monetary incentives. For policymakers, our results might nevertheless be welcome as we find households to act rather rational in the sense of investors weighing up the costs and benefits of their decisions. Since it is economic factors that trigger the decision to invest in a renewable energy system, the policymaker may provide reasonable financial incentives in order to steer households in the desired direction for climate protection.

\section{Acknowledgements}

Anke Jacksohn gratefully acknowledges financial support from the Gesellschaft für Energie und Klimaschutz Schleswig-Holstein GmbH (EKSH, Association for Energy and Climate Protection SchleswigHolstein)

\section{Role of the funding source}

Anke Jacksohn received financial support in form of a scholarship from the Gesellschaft für Energie und Klimaschutz Schleswig-Holstein GmbH (EKSH, Association for Energy and Climate Protection Schleswig-Holstein). The EKSH was not involved in the study design, data collection, analysis and interpretation of data, writing of the paper or in the decision to submit the paper for publication. 


\section{References}

Agarwal, A, Cai, D, Shah, S, Chandy, M, Sherick, R, 2015. A model for residential adoption of solar photovolatic systems. 2015 IEEE Power and Energy Society General M eeting, pp. 1-5.

Altenhöfer-Pflaum, G, Horbelt, R, 2017. National Survey Report of PV Power Applications in Germany 2015. IEA Photovoltaic Power Systems Programme.

Alyousef, A, Adepetu, A, de Meer, H, 2016. Analysis and model-based predictions of solar PV and battery adoption in Germany: an agent based approach. Computer Science - Research and Development, published online: 15 July 2016.

Balcombe, P, Rigby, D, Azapagic, A, 2013. M otivations and barriers associated with adopting microgeneration energy technologies in the UK. Renewable and Sustainable Energy Reviews 22, 655666.

BKI, 2008, 2009, 2010. Baukosten - Teil 2: Statistische Kostenkennwerte für Bauelemente. Stuttgart: Baukosteninformationszentrum Deutscher Architektenkammern.

BKI, 2011, 2012, 2013 2014. Baukosten Bauelemente - Statistische Kostenkennwerte. Stuttgart: Baukosteninformationszentrum Deutscher Architektenkammern.

BKI 2015. Baukosten Bauelemente Neubau - Statistische Kostenkennwerte. Stuttgart: Baukosteninformationszentrum Deutscher Architektenkammern.

Braito, M, Flint, C, M uhar, A, Penker, M, Vogel, S, 2017. Individual and collective socio-psychological patterns of photovoltaic investment under diverging policy regimes in Austria and Italy. Energy Policy 109, 141-153.

Bundesministerium für Wirtschaft und Energie, 2015. Richtlinien zur Förderung von Maßnahmen zur Nutzung erneuerbarer Energien im Wärmemarkt vom 11. März 2015. BAnz AT 25.03.2015 B1.

Bundesministerium für Wirtschaft und Energie, 2017. Zahlen und Fakten Energiedaten, Stand 05.05.2017.

Busic-Sontic, A, Brick, C, 2018. Personality trait effects on green household installations. Collabra: Psychology 4(1): 8.

Busic-Sontic, A, Fuerst, F, 2017. The personality profiles of early adopters of energy-efficient technology. SOEPpapers on Multidisciplinary Panel Data Research at DIW Berlin No. 924, Berlin.

Costa, P, M cCrae, R, 1992. Revised Neo Personality Inventory (NEO-PI-R) and NEO Five Factor Inventory (NEO-FFI). Psychological Assessment Resources (Odessa).

DWD Climate Data Center (CDC): Rasterdaten der vieljährigen mittleren M onatssummen und der vieljährigen mittleren Jahressumme für die Globalstrahlung auf die horizontale Ebene für Deutschland basierend auf Boden- und Satellitenmessungen, Version V002, 2016. 
EEG, 2000. Gesetz für den Vorrang Erneuerbarer Energien (Erneuerbare-Energien-Gesetz - EEG) sowie zur Änderung des Energiewirtschaftsgesetzes und M ineralölsteuergesetzes vom 29. M ärz 2000 (BGBI. I S. 305).

EEG, 2004. Erneuerbare-Energien-Gesetz vom 21. Juli 2004 (BGBI. I S. 1918), zuletzt geändert durch Artikel 1 des Gesetzes vom 7. November 2006 (BGBI. I S. 2550).

Erneuerbare Energien Wärmegesetz, 2008. Erneuerbare-Energien-Wärmegesetz vom 7. August 2008 (BGBI. I S. 1658), das zuletzt durch Artikel 9 des Gesetzes vom 20. Oktober 2015 (BGBI. I S. 1722) geändert worden ist.

Ferguson, CJ, 2010. A meta-analysis of normal and disordered personality across the life span. Journal of Personality and Social Psychology 98(4), 659-667.

Gerlitz, JY, Schupp, J, 2005. Zur Erhebung der Big-Five-basierten Persönlichkeitsmerkmale im SOEP Dokumentation der Instrumententwicklung BFI-S auf Basis des SOEP-Pretests 2005. Research Notes 4, DIW, Berlin.

Gröger, M, Schmid, V, Bruckner, T, 2011. Lifestyles and their impact on energy-related investment decisions. Low Carbon Economy 2, 107-114.

Haisken-DeNew, JP, Frick, JR, 2005. Desktop Companion to the German Socio-Economic Panel (SOEP). Version 8.0, December 2005.

Heiskanen, E, M atschoss, K, 2017. Understanding the uneven diffusion of building-scale renewable energy systems: A review of household, local and country level factors in diverse European countries. Renewable and Sustainable Energy Reviews 75, 580-591.

John, OP, Donahue, EM, Kentle, RL, 1991. The "Big Five" Inventory - Versions 4a and 54. Berkeley, University of California, Institute of Personality and Social Research.

John, OP, Naumann, LP, Soto, CJ, 2008. Paradigm Shift to the Integrative Big Five Trait Taxonomy. In John, OP, Robins, R., Pervin, L, (eds.), Handbook of Personality: Theory and Research, New York: Guilford, pp. 114-158.

Karakaya, E, Hidalgo, A, Nuur, C, 2015. M otivators for adoption of photovoltaic systems at grid parity: A case study from Southern Germany. Renewable and Sustainable Energy Reviews 43, 1090-1098.

Kastner, I, Matthies, E, 2016. Investments in renewable energies by German households: A matter of economics, social influences and ecological concern? Energy Research and Social Science 17, 1-9.

Kastner, I, Stern, PC, 2015. Examining the decision-making processes behind household energy investments: A review. Energy Research and Social Science 10, 72-89.

Kotilainen, K, Valta, J, M äkinen, SJ, 2017. Understanding consumers' renewable energy behaviour beyond "homo economicus": An explanatory survey in four European countries. 14th International Conference on the European Energy M arket (EEM), 2017. 
Lucas, RE, Donnellan, MB, 2011. Personality development across the life span: Longitudinal analyses with a national sample from Germany. Journal of Personality and Social Psychology 101(4), 847-861.

M cCrae, R, Costa, P, 2008. The five-factor theory of personality. In John, OP, Robins, R., Pervin, L, (eds.), Handbook of Personality: Theory and Research, New York: Guilford, pp. 159-181.

M cCrae, R, John, OP, 1992. An introduction to the five-factor model and its applications. Journal of Personality 60, 175-215.

M ichelsen, CC, M adlener, R, 2012. Homeowners' preferences for adopting innovative residential heating systems: A discrete choice analysis for Germany. Energy Economics 34, 1271-1283.

M ichelsen, CC, M adlener, R, 2013. M otivational factors influencing the homeowners' decisions between residential heatingsystems: An empirical analysis for Germany. Energy Policy 57, 221-233.

M ichelsen, CC, M adlener, R, 2016. Switching from fossil fuel to renewables in residential heating systems: An empirical study of homeowners' decisions in Germany. Energy Policy 89, 95-105.

M ilbert, A, 2015. Raumabgrenzungen - M ethodik und Entwicklung der BBSR-Typen. In: M einel, G, Schumacher, U, Behnisch, M , Krüger, T (Hrsg.): Flächennutzungsmonitoring VII. Boden Flächenmanagment - Analysen und Szenarien. Berlin: Rhombos-Verlag.

M ills, BF, Schleich, J, 2009. Profits or preferences? Assessing the adoption of residential solar thermal technologies. Energy Policy 37, 4145-4154.

OECD, 2013. OECD Framework for Statistics on the Distribution of Household Income, Consumption and Wealth. OECD Publishing. doi: 10.1787/9789264194830-en

Palm, J, 2018. Household installations of solar panels - M otives and barriers in a 10-year perspective. Energy Policy 113, 1-8.

Rai, V, Robinson, SA, 2015. Agent-based modeling of energy technology adoption: Empirical integration of social, behavioral, economic, and environmental factors. Environmental M odelling and Software 70, 163-177.

Richter, D, Rohrer, J, Metzing, M, Nestler, W, Weinhardt, M, Schupp, J, 2017. SOEP scales manual (updated for SOEP-Core v32.1). SOEP Survey Papers No. 423, DIW, Berlin.

Robinson, SA, Rai, V, 2015. Determinants of spatio-temporal patterns of energy technology adoption: An agent-based modeling approach. Applied Energy 151, 273-284.

Sonnberger, M, 2015. Der Erwerb von Photovoltaikanlagen in Privathaushalten - Eine empirische Untersuchung der Handlungsmotive, Treiber und Hemmnisse. Dissertation an der Universität Stuttgart, 2014. Springer.

Specht, J, Egloff, B, Schmukle, SC, 2011. Stability and change of personality across the life course: The impact of age and major life events on mean-level and rank-order stability of the Big Five. Journal of Personality and Social Psychology 101(4), 862-882. 
Train, KE, 2009. Discrete Choice M ethods with Simulations, $2^{\text {nd }}$ Edition, Cambridge University Press, Cambridge.

Wagner, GG, Frick, JR, Schupp, J, 2007. The German Socio-Economic Panel Study (SOEP) - Scope, Evolution and Enhancements. Schmollers Jahrbuch 127(1), 139-169.

Wasi, N, Carson, RT, 2013. The influence of rebate programmes on the demand for water heaters: The case of New South Wales. Energy Economics 40, 645-656.

Welsch, H, Kühling, J, 2009. Determinants of pro-environmental consumption: The role of reference groups and routine behaviour. Ecological Economics 69, 166-176.

Wesselak, V, Schabbach, T, Link, T, Fischer, J, 2017. Handbuch Regenerative Energietechnik, 3. Auflage. Berlin: Springer Vieweg.

Wirth, H, 2016. Aktuelle Fakten zur Photovoltaik in Deutschland. Fraunhofer Institut für Solare Energiesysteme ISE, Freiburg. 


\section{Appendix A: Assembly of installation costs and expected revenues of a PV and ST system}

To make the investment costs comparable between PV and ST systems, we convert the PV system costs (given as net costs in euros per $\mathrm{kW}_{\mathrm{p}}$ ) taken from Altenhöfer-Pflaum and Horbelt (2017) to gross costs in euros per square meter. We calculate

$$
\frac{\left(€ / k W_{p}\right) * 1.19}{10 m^{2} / k W_{p}}=\frac{€}{m^{2}}
$$

using the value-added tax of $19 \%$ and the fact that one $\mathrm{kW}_{\mathrm{p}}$ of capacity requires roughly ten square meters of collector area (Wesselak et al., 2017).

Unlike costs, revenues attainable with a solar energy system do not only vary with the technology and over time $t$ but also depend on the local abundance of solar irradiance in household $h$ 's county of residence $c$. Hence, we use $1 \mathrm{~km} \times 1 \mathrm{~km}$ raster data on the mean sums of annual global radiation provided by the Germany's National Meteorological Service (DWD) to calculate the mean sum of annual global radiation for each of the 402 counties in Germany and merge it with the SOEP data based on the household county code contained therein. ${ }^{12}$

The additional variables and parameters used to calculate the attainable revenues are displayed in Table A1, while formulas (A2) to (A4) detail the calculation of the revenues attainable with a PV system $\left(\right.$ revenue $\left._{c t}^{p v}\right)$, an ST system (revenue $\left.e_{c t}^{s t}\right)$ or a combination of both systems (revenue rtt $\left.^{\text {both }}\right)$.

12 The average area of a county is approximately $890 \mathrm{~km}^{2}$. 
Table A1. Variables and parameters used in the calculation of attainable revenues

\begin{tabular}{|c|c|c|c|c|}
\hline & Abbreviation & Unit & Range & Source \\
\hline $\begin{array}{l}\text { Mean annual global } \\
\text { radiation (county level) }\end{array}$ & $g r_{c}$ & $\frac{k W h}{\left(m^{2} / \text { year }\right)}$ & $968.379-1187.001$ & $\begin{array}{l}\text { DWD Climate Data } \\
\text { Center (2016) }\end{array}$ \\
\hline \multicolumn{5}{|l|}{$\underline{P V}$} \\
\hline Feed-in tariff & fit $_{t}$ & $\frac{\text { cents }}{k W h}$ & $46.75-12.40$ & $\begin{array}{l}\text { EEG (2004); } \\
\text { Bundesnetzagentur }{ }^{13}\end{array}$ \\
\hline Effectiveness & $\eta$ & & 0.12 & Wirth (2016) \\
\hline Performance ratio & $\mathrm{pr}$ & & 0.80 & \\
\hline \multicolumn{5}{|l|}{$\underline{\mathrm{ST}}$} \\
\hline Gas price & $g p_{t}$ & $\frac{\text { cents }}{k W h}$ & $6.36-7.14$ & $\begin{array}{l}\text { Bundesministerium für } \\
\text { Wirtschaft und Energie } \\
\text { (2017) }\end{array}$ \\
\hline $\begin{array}{l}\text { Number of persons } \\
\text { living in the household }\end{array}$ & hh_size ht & & $1-14$ & SOEP \\
\hline $\begin{array}{l}\text { Annual energy } \\
\text { requirement for hot } \\
\text { water per person }\end{array}$ & er & $\frac{\frac{k W h}{\left(m^{2} / \text { year }\right)}}{\text { person }}$ & 1000 & Verbraucherzentrale $e^{14}$ \\
\hline Collector area & $\mathrm{ca}$ & $\frac{m^{2}}{\text { person }}$ & 1.5 & Verbraucherzentrale $e^{15}$ \\
\hline $\begin{array}{l}\text { Mean annual global } \\
\text { radiation in Germany } \\
\text { for the period 1981- } \\
2010\end{array}$ & gr & $\frac{k W h}{\left(m^{2} / \text { year }\right)}$ & 1054 & DWD 16 \\
\hline $\begin{array}{l}\text { Fraction of the energy } \\
\text { requirement for warm } \\
\text { water covered by the ST } \\
\text { system }\end{array}$ & sf & & 0.55 & Verbraucherzentrale $e^{17}$ \\
\hline
\end{tabular}

\footnotetext{
${ }^{13} \mathrm{https}$ // www.bundesnetzagentur.de/DE/Sachgebiete/ElektrizitaetundGas/Unternehmen_Institutionen/Erneu erbareEnergien/ZahlenDatenInformationen/EEG_Registerdaten/ArchivDatenM eldgn/ArchivDatenM eldgn_nod e.html, last accessed 30.05.2018

${ }^{14} \mathrm{https}$ ://www.verbraucherzentrale.de/solarthermie, last accessed 30.05.2018

${ }^{15} \mathrm{https://www.verbraucherzentrale.de/solarwaerme-fuer-warmwasser-und-heizung-3,} \mathrm{last} \mathrm{accessed}$ 30.05 .2018

${ }^{16} \mathrm{https}$ ://www.dwd.de/DE/leistungen/solarenergie//strahlungskarten_mi.html?nn=16102, last accessed 30.05.2018

${ }^{17}$ https://www.verbraucherzentrale.de/solarwaerme-fuer-warmwasser-und-heizung-3, last accessed 30.05.2018
} 
In the calculation of the revenue attainable with a PV system, we take account of mean annual global radiation at county level, the feed-in tariff for electricity produced with small-scale PV systems in the year of installation and the effectiveness and performance ratio of such systems.

$$
\text { revenue }_{c t}^{p v}=\frac{f i t_{t} * g r_{c} * \eta * p r}{100}
$$

The feed-in tariff that households receive for each kWh of electricity fed into the grid is laid down by the German Renewable Energy Sources Act (Erneuerbare Energien Gesetz, EEG) and guaranteed for 20 years. Introduced in 2000, the EEG initially established a feed-in tariff of 50.6 Cent/ kWh for electricity from solar energy (EEG, 2000). During the years considered in our analysis, the feed-in tariff for smallscale PV systems was gradually reduced from 46.75 cents/ kWh in 2008 to 12.31 cents/kWh at the end of 2015 in response to the progressing decrease in system costs.

For ST systems, we base our calculation on typical values for the dimensioning of such a system used for hot water provisioning. Further, we consider revenue in terms of the foregone expenditures on fossil fuel-based water heating. Global radiation at county level is normalized by the mean value of global radiation for the whole of Germany thus scaling attainable revenue up or down depending on local conditions.

$$
\text { revenue }_{c t}^{s t}=\frac{\frac{s f * e r * h h_{\text {size }_{h t}} * g p_{t} * \frac{g r_{c}}{g r}}{h h_{\text {size }_{h t}} * c a}}{100}
$$

Since we have no information on the size of the PV and ST systems, we assume an equal split of revenues for those households that equip their dwelling with a combination of the two and calculate the attainable revenue accordingly.

$$
\text { revenue }_{c t}^{\text {both }}=0.5 * \text { revenue }_{c t}^{p v}+0.5 * \text { revenue }_{c t}^{s t}
$$




\section{Appendix B: Further descriptives and results}

\section{Table B1. Sample restrictions}

\begin{tabular}{|c|c|c|c|c|c|c|c|c|c|}
\hline & 2008 & 2009 & 2010 & 2011 & 2012 & 2013 & 2014 & 2015 & Total \\
\hline SOEP v32 & 11,058 & 11,889 & 15,414 & 16,819 & 16,508 & 18,093 & 16,037 & 15,991 & 121,809 \\
\hline w/o households w/ o interview in 2015 & 6,120 & 6,235 & 8,666 & 11,074 & 12,296 & 14,120 & 14,091 & 15,991 & 88,593 \\
\hline $\begin{array}{l}\text { w/o tenants } \\
\text { w/o households occupying high-rise buildings and }\end{array}$ & 3,186 & 3,231 & 4,129 & 5,274 & 5,836 & 6,351 & 6,402 & 6,756 & 41,165 \\
\hline buildings w/o classification & 3,168 & 3,214 & 4,108 & 5,250 & 5,813 & 6,321 & 6,367 & 6,721 & 40,962 \\
\hline w/o household-years in previous dwellings & 2,909 & 2,977 & 3,820 & 4,965 & 5,579 & 6,151 & 6,278 & 6,721 & 39,400 \\
\hline w/o households with a solar energy system in 2007 & 2,646 & 2,710 & 3,558 & 4,700 & 5,312 & 5,881 & 6,011 & 6,451 & 37,269 \\
\hline w/o first household-year after (re-)entry into the SOEPb & 2,604 & 2,679 & 2,751 & 3,458 & 4,415 & 5,049 & 5,499 & 5,723 & 32,178 \\
\hline w/o households who moved into existing dwellings with solar & 2,602 & 2,670 & 2,738 & 3,435 & 4,382 & 5,006 & 5,415 & 5,623 & 31,871 \\
\hline w/o households with solar energy system of unknown type & 2,517 & 2,585 & 2,653 & 3,328 & 4,253 & 4,864 & 5,264 & 5,481 & 30,945 \\
\hline w/o household-years after solar energy system adoption & 2,517 & 2,556 & 2,573 & 3,211 & 4,075 & 4,607 & 4,966 & 5,128 & 29,633 \\
\hline w/o missing information on most frequent household head & 2,516 & 2,556 & 2,573 & 3,210 & 4,074 & 4,603 & 4,947 & 5,084 & 29,563 \\
\hline w/o missing household or individual information & 2,446 & 2,484 & 2,499 & 2,522 & 3,161 & 3,644 & 3,663 & 3,717 & 24,136 \\
\hline
\end{tabular}

a This includes households that already had a solar energy system as tenants and subsequently became owners of their dwelling.

${ }^{b}$ Households with a solar energy system in the year of (re-)entry are excluded completely. 
Table B2. Different functional forms of income

\begin{tabular}{|c|c|c|c|c|c|c|c|c|c|c|}
\hline \multirow{4}{*}{ 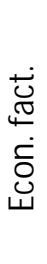 } & \multirow[b]{2}{*}{ Costs } & \multicolumn{3}{|c|}{ linear } & \multicolumn{3}{|c|}{$\wedge^{2}$} & \multicolumn{3}{|c|}{$\wedge$} \\
\hline & & & $\begin{array}{l}-3.290^{* * *} \\
(0.889)\end{array}$ & & & $\begin{array}{l}-3.277^{* *} \\
(0.884)\end{array}$ & & & $\begin{array}{l}-3.255^{* * *} \\
(0.882)\end{array}$ & \\
\hline & Revenue & & $\begin{array}{l}0.980^{* * *} \\
(0.361)\end{array}$ & & & $\begin{array}{l}0.952^{* * *} \\
(0.360)\end{array}$ & & & $\begin{array}{l}0.954 * * * \\
(0.359)\end{array}$ & \\
\hline & & $\underline{P V}$ & $\underline{\mathrm{ST}}$ & Both & PV & $\underline{\mathrm{ST}}$ & Both & PV & $\underline{\mathrm{ST}}$ & Both \\
\hline$\frac{2}{0}$ & Concern & $\begin{array}{l}0.172 * \\
(0.096)\end{array}$ & $\begin{array}{l}0.084 \\
(0.096)\end{array}$ & $\begin{array}{l}0.075 \\
(0.217)\end{array}$ & $\begin{array}{l}0.163^{*} \\
(0.095)\end{array}$ & $\begin{array}{l}0.082 \\
(0.096)\end{array}$ & $\begin{array}{l}0.073 \\
(0.216)\end{array}$ & $\begin{array}{l}0.162 * \\
(0.096)\end{array}$ & $\begin{array}{l}0.078 \\
(0.095)\end{array}$ & $\begin{array}{l}0.073 \\
(0.217)\end{array}$ \\
\hline$\frac{\bar{n}}{\bar{Q}}$ & Consc & $\begin{array}{l}-0.164 * \\
(0.087)\end{array}$ & $\begin{array}{l}0.047 \\
(0.096)\end{array}$ & $\begin{array}{l}0.284 \\
(0.207)\end{array}$ & $\begin{array}{l}-0.156 * \\
(0.086)\end{array}$ & $\begin{array}{l}0.048 \\
(0.096)\end{array}$ & $\begin{array}{l}0.290 \\
(0.208)\end{array}$ & $\begin{array}{l}-0.156 * \\
(0.086)\end{array}$ & $\begin{array}{l}0.050 \\
(0.096)\end{array}$ & $\begin{array}{l}0.284 \\
(0.206)\end{array}$ \\
\hline $\begin{array}{l}\text { Q } \\
\frac{\varepsilon}{0} \\
\varepsilon\end{array}$ & Extrav & $\begin{array}{l}-0.006 \\
(0.098)\end{array}$ & $\begin{array}{l}0.012 \\
(0.099)\end{array}$ & $\begin{array}{l}0.015 \\
(0.170)\end{array}$ & $\begin{array}{l}-0.004 \\
(0.098)\end{array}$ & $\begin{array}{l}0.013 \\
(0.098)\end{array}$ & $\begin{array}{l}0.015 \\
(0.170)\end{array}$ & $\begin{array}{l}-0.005 \\
(0.097)\end{array}$ & $\begin{array}{l}0.014 \\
(0.098)\end{array}$ & $\begin{array}{l}0.013 \\
(0.167)\end{array}$ \\
\hline ఫ్ & Agree & $\begin{array}{l}-0.007 \\
(0.087)\end{array}$ & $\begin{array}{l}-0.082 \\
(0.091)\end{array}$ & $\begin{array}{l}-0.250 \\
(0.188)\end{array}$ & $\begin{array}{l}-0.008 \\
(0.088)\end{array}$ & $\begin{array}{l}-0.081 \\
(0.091)\end{array}$ & $\begin{array}{l}-0.247 \\
(0.190)\end{array}$ & $\begin{array}{l}-0.009 \\
(0.088)\end{array}$ & $\begin{array}{l}-0.079 \\
(0.092)\end{array}$ & $\begin{array}{l}-0.245 \\
(0.187)\end{array}$ \\
\hline סे & Open & $\begin{array}{l}0.101 \\
(0.104)\end{array}$ & $\begin{array}{l}0.072 \\
(0.112)\end{array}$ & $\begin{array}{l}-0.041 \\
(0.215)\end{array}$ & $\begin{array}{l}0.089 \\
(0.103)\end{array}$ & $\begin{array}{l}0.067 \\
(0.113)\end{array}$ & $\begin{array}{l}-0.056 \\
(0.213)\end{array}$ & $\begin{array}{l}0.088 \\
(0.103)\end{array}$ & $\begin{array}{l}0.059 \\
(0.113)\end{array}$ & $\begin{array}{l}-0.054 \\
(0.212)\end{array}$ \\
\hline ธ์ & Neuro & $\begin{array}{l}-0.070 \\
(0.099)\end{array}$ & $\begin{array}{l}-0.048 \\
(0.105)\end{array}$ & $\begin{array}{l}-0.157 \\
(0.191)\end{array}$ & $\begin{array}{l}-0.060 \\
(0.099)\end{array}$ & $\begin{array}{l}-0.046 \\
(0.104)\end{array}$ & $\begin{array}{l}-0.148 \\
(0.190)\end{array}$ & $\begin{array}{l}-0.057 \\
(0.100)\end{array}$ & $\begin{array}{l}-0.032 \\
(0.105)\end{array}$ & $\begin{array}{l}-0.155 \\
(0.191)\end{array}$ \\
\hline$\frac{y}{n}$ & Age & $\begin{array}{l}-0.456 * * * \\
(0.105)\end{array}$ & $\begin{array}{l}-0.174 \\
(0.116)\end{array}$ & $\begin{array}{l}0.145 \\
(0.218)\end{array}$ & $\begin{array}{l}-0.423 * * * \\
(0.107)\end{array}$ & $\begin{array}{l}-0.164 \\
(0.116)\end{array}$ & $\begin{array}{l}0.176 \\
(0.210)\end{array}$ & $\begin{array}{l}-0.414 * * * \\
(0.106)\end{array}$ & $\begin{array}{l}-0.122 \\
(0.115)\end{array}$ & $\begin{array}{l}0.148 \\
(0.210)\end{array}$ \\
\hline 这 & Female & $\begin{array}{l}-0.226^{* *} \\
(0.104)\end{array}$ & $\begin{array}{l}0.063 \\
(0.099)\end{array}$ & $\begin{array}{l}-0.044 \\
(0.203)\end{array}$ & $\begin{array}{l}-0.225 * * \\
(0.105)\end{array}$ & $\begin{array}{l}0.064 \\
(0.099)\end{array}$ & $\begin{array}{l}-0.033 \\
(0.205)\end{array}$ & $\begin{array}{l}-0.224^{* *} \\
(0.105)\end{array}$ & $\begin{array}{l}0.069 \\
(0.099)\end{array}$ & $\begin{array}{l}-0.037 \\
(0.205)\end{array}$ \\
\hline $\begin{array}{l}\tilde{5} \\
\text { g }\end{array}$ & LowEdu & $\begin{array}{l}0.171 \\
(0.123)\end{array}$ & $\begin{array}{l}-0.370^{*} \\
(0.209)\end{array}$ & $\begin{array}{l}0.043 \\
(0.173)\end{array}$ & $\begin{array}{l}0.208^{*} \\
(0.125)\end{array}$ & $\begin{array}{l}-0.358^{*} \\
(0.211)\end{array}$ & $\begin{array}{l}0.094 \\
(0.185)\end{array}$ & $\begin{array}{l}0.213^{*} \\
(0.126)\end{array}$ & $\begin{array}{l}-0.327 \\
(0.212)\end{array}$ & $\begin{array}{l}0.055 \\
(0.198)\end{array}$ \\
\hline 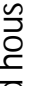 & M ediumEdu & $\begin{array}{l}0.231^{* *} \\
(0.103)\end{array}$ & $\begin{array}{l}-0.042 \\
(0.104)\end{array}$ & $\begin{array}{l}-0.374 * \\
(0.199)\end{array}$ & $\begin{array}{l}0.260 * * * \\
(0.101)\end{array}$ & $\begin{array}{l}-0.032 \\
(0.104)\end{array}$ & $\begin{array}{l}-0.331 \\
(0.205)\end{array}$ & $\begin{array}{l}0.261 * * * \\
(0.101)\end{array}$ & $\begin{array}{l}-0.019 \\
(0.102)\end{array}$ & $\begin{array}{l}-0.341 \\
(0.213)\end{array}$ \\
\hline है & EqIncome & $\begin{array}{l}0.419 * * * \\
(0.076)\end{array}$ & $\begin{array}{l}0.214^{* *} \\
(0.089)\end{array}$ & $\begin{array}{l}0.179 \\
(0.148)\end{array}$ & $\begin{array}{l}1.063 * * * \\
(0.292)\end{array}$ & $\begin{array}{l}0.403 \\
(0.344)\end{array}$ & $\begin{array}{l}0.801 \\
(0.643)\end{array}$ & $\begin{array}{l}1.721^{*} \\
(0.895)\end{array}$ & $\begin{array}{l}\text { 3.749*** } \\
(1.218)\end{array}$ & $\begin{array}{l}-1.456 \\
(1.437)\end{array}$ \\
\hline$\frac{0}{8}$ & EqIncome^2 & & & & $\begin{array}{l}-0.574 * * \\
(0.263)\end{array}$ & $\begin{array}{l}-0.171 \\
(0.327)\end{array}$ & $\begin{array}{l}-0.555 \\
(0.489)\end{array}$ & $\begin{array}{l}-1.917 \\
(1.746)\end{array}$ & $\begin{array}{l}-7.004 * * * \\
(2.342)\end{array}$ & $\begin{array}{l}4.185 \\
(2.764)\end{array}$ \\
\hline$n$ & Eqlncome^3 & & & & & & & $\begin{array}{l}0.743 \\
(0.947)\end{array}$ & $\begin{array}{l}3.740 * * * \\
(1.243)\end{array}$ & $\begin{array}{l}-2.744^{*} \\
(1.526)\end{array}$ \\
\hline
\end{tabular}




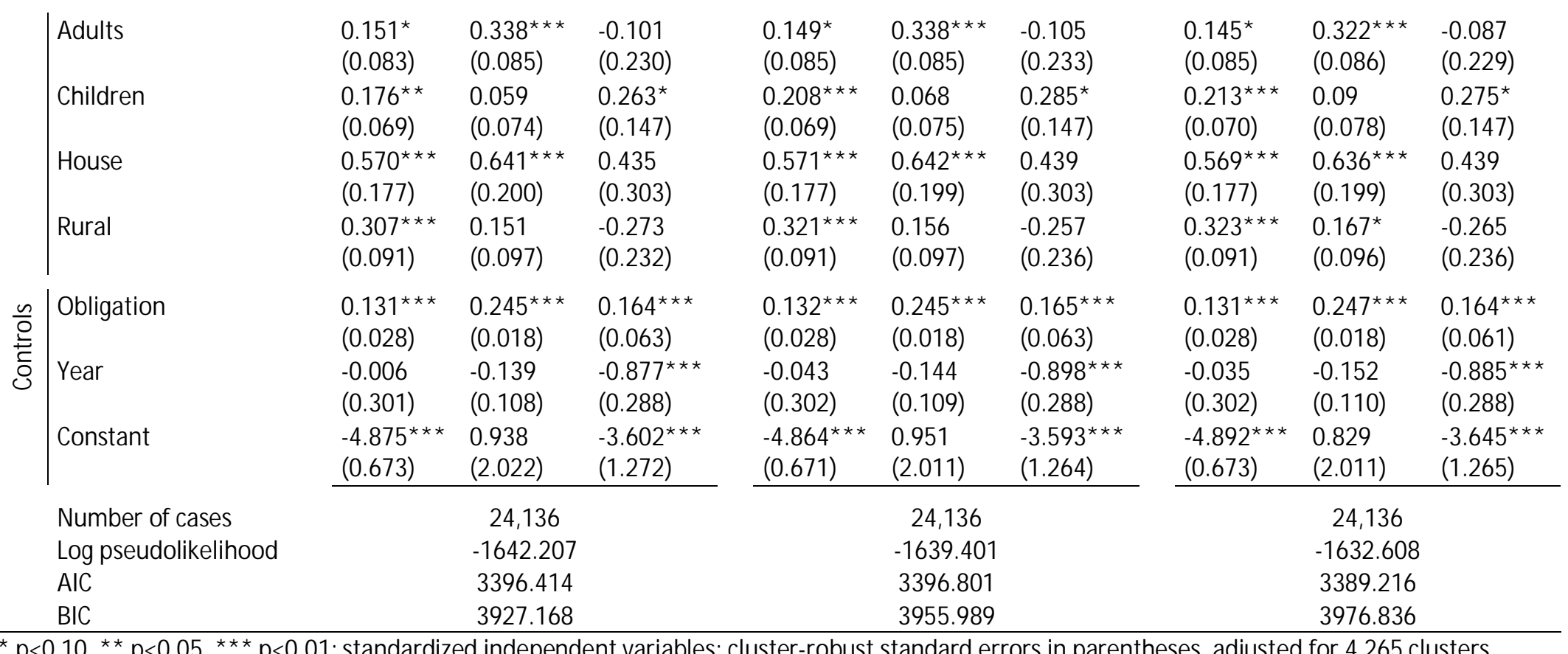


Table B3. Results of the Wald tests for equality of cost coefficients across models

\begin{tabular}{lcc}
\hline & Model 1 & Model 2 \\
\hline Model 1 & - & - \\
Model 2 & $p=0.846$ & - \\
Model 3 & $p=0.300$ & $p=0.229$ \\
\hline
\end{tabular}

Table B4. Results of the Wald tests for equality of revenue coefficients across models

\begin{tabular}{lcc}
\hline & Model 1 & Model 2 \\
\hline Model 1 & - & - \\
Model 2 & $p=0.428$ & - \\
Model 3 & $p=0.323$ & $p=0.441$ \\
\hline
\end{tabular}

